Volume 13, Nomor 1, Mei 2021, pp 109-117 Copyright (C) 2017

Jurnal Akuntansi, Program Studi Akuntansi, Fakultas Bisnis,

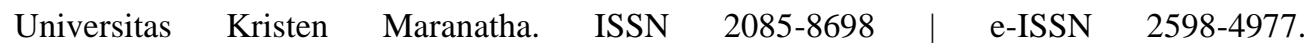

http://journal.maranatha.edu

\title{
"Replika Endemi" \\ Resistensi PSAK 71 Sebagai Countercyclical Terhadap Sustainability Perbankan Ditengah Pandemi
}

\author{
Nicholas Alexander Tungga ${ }^{1}$ \\ Universitas Katolik Widya Mandala \\ J1 Dinoyo 42-44 Surabaya \\ nichoalexander1999@gmail.com \\ Melithasya Angelina ${ }^{2}$ \\ Universitas Katolik Widya Mandala \\ J1 Dinoyo 42-44 Surabaya \\ melithasyaa@gmail.com \\ Elliza $^{3}$ \\ Universitas Katolik Widya Mandala \\ J1 Dinoyo 42-44 Surabaya \\ angelineelliza@gmail.com
}

\begin{abstract}
Financial reports are important because they are useful for providing an overview for stakeholders in their decision making. Where in the preparation of financial statements the main regulation used is the Statement of Financial Accounting Standards (PSAK) established by the Indonesian Institute of Accountants (IAI) through the Financial Accounting Standards Board (DSAK). In the current status quo of Indonesia in facing the Covid-19 pandemic, the existence of PSAK has begun to be tested, adjustments must be made to financial accounting standards which are useful to strengthen the lines of corporate accountability in Indonesia and are able to answer the main urgency of Indonesia today, namely the weakening of the country's economy. The purpose of this paper is to produce a framework that can later become an alternative for banks in making decisions for implementing the PSAK 71 post model. The approach used in this paper is a qualitative approach by providing arguments and solutions for Indonesia's current economic conditions through the resulting framework design. After considering the aspects that affect the risk of bad credit, the conclusion is that PSAK 71 is able to trigger an economic upturn in Indonesia, because in its implementation it does not necessarily look at one aspect only but considers other aspects in responding to issues related to bad credit.
\end{abstract}

Keywords: PSAK 71, Post Model Framework, Bad Credit, Indonesian Economy 


\begin{abstract}
Abstrak
Laporan keuangan menjadi penting karena berguna untuk memberikan gambaran bagi para pemangku kepentingan dalam pengambilan keputusan mereka. Dimana dalam penyusunan laporan keuangan regulasi utama yang digunakan adalah Pernyataan Standar Akuntansi Keuangan (PSAK) yang ditetapkan oleh Ikatan Akuntan Indonesia (IAI) melalui Dewan Standar Akuntansi Keuangan (DSAK). Pada status quo Indonesia saat ini dalam menghadapi pandemi Covid-19 eksistensi PSAK mulai diuji, penyesuaian-penyesuaian harus dilakukan pada standar akuntansi keuangan yang berguna untuk memperkuat lini dari akuntabilitas perusahaan di Indonesia dan mampu menjawab urgensi utama Indonesia saat ini yakni melemahnya perekonomian negara. Tujuan dari penulisan ini adalah menghasilkan framework yang nantinya dapat menjadi alternatif bank dalam mengambil keputusan untuk penerapan post model PSAK 71. Pendekatan yang digunakan dalam penulisan ini adalah pendekatan kualitatif dengan memberikan argumen serta solusi untuk kondisi ekonomi Indonesia saat ini melalui rancangan framework yang dihasilkan. Setelah mempertimbangkan aspek- aspek yang berpengaruh terhadap risiko kredit macet maka dihasilkan kesimpulan bahwa PSAK 71 mampu memicu naiknya perekonomian di Indonesia, karena dalam pelaksanaannya tidak serta merta hanya melihat pada satu aspek saja namun mempertimbangkan aspek lain dalam menanggapi isu terkait kredit macet.
\end{abstract}

Kata Kunci: PSAK 71, Post Model Framework, Kredit Macet, Perekonomian Indonesia

\section{Pendahuluan}

\section{Latar Belakang}

Laporan keuangan merupakan salah satu hal urgensi dalam suatu entitas bisnis, mengingat laporan keuangan merupakan komponen yang digunakan entitas maupun pemangku kepentingan dalam proses pengambilan keputusan. Penyusunan laporan keuangan yang benar harus mengikuti regulasi yang berlaku, sesuai Pernyataan Standar Akuntansi Keuangan (PSAK) yang berbasis pada Intenational Financial Reporting Standard (IFRS). PSAK sendiri merupakan basis bagi perusahaan, auditor, maupun pemangku kepentingan dalam melakukan fungsinya yang berhubungan dengan laporan keuangan.
Awal kuartal pertama tahun 2020 dunia digemparkan dengan masalah global mengenai kesehatan yaitu munculnya wabah Coronavirus disease 2019 (Covid19). Fenomena tersebut mempengaruhi banyak lini di Indonesia, salah satunya lini bisnis yang berujung pada melemahnya ekonomi nasional. Melemahnya ekonomi nasional memberikan dampak signifikan terhadap perusahaan-perusahaan di Indonesia khususnya pada sektor perbankan. Hal-hal yang menjadi perhatian khusus adalah terkait kemampuan bayar debitur atas pinjaman dana mereka kepada kreditur baik bank maupun entitas bisnis pemberi pinjaman. Saat ini banyak masyarakat yang sangat bergantung pada kredit dalam kehidupan ekonomi, misalnya untuk pergantian modal bisnis.

Pemerintah melalui Ikatan Akuntan Indonesia (IAI) melakukan penyesuaian 
terhadap beberapa PSAK yang disampaikan dalam press release IAI. PSAK yang terdampak diantaranya, PSAK 8 mengenai peristiwa setelah periode pelaporan, PSAK 68 mengenai pengukuran nilai wajar, dan PSAK 71 terkait instrumen keuangan. Dewan Standar Akuntansi Keuangan (DSAK) dalam press releasenya menekankan bahwa penyesuaian yang dilakukan tidak merubah bentuk asli dari pernyataan tersebut.

Penerapan PSAK 71 dinilai memberikan dampak yang lebih baik terhadap antisipasi kerugian yang terjadi akibat berbagai peristiwa tidak terduga seperti fenomena Covid-19 ini dibandingkan dengan PSAK 55. Ketika situasi tidak terduga terjadi, dampak yang baik dari pendekatan Expected Credit Loss (ECL) akan terlihat karena bank memiliki ketentuan kerugian pinjaman yang telah dicadangkan di awal. PSAK 71 mulai berlaku per 1 Januari 2020 dan mulai diuji eksistensinya pada masa pandemi ini. Terkait pengimplementasian PSAK 71 di Indonesia dan kondisi yang telah dipaparkan, makalah ini memberikan keyakinan bahwa adaptasi PSAK 71 di tengah pandemi Covid-19 mampu menstimulus perekonomian yang ada di Indonesia.

Pertama, strategi terkait efektifitas PSAK 71 untuk menghadapi fenomena Covid-19 akan diuraikan. Selanjutnya makalah ini akan mengusulkan kerangka kerja ketentuan pencadangan kerugian pinjaman untuk kreditor dalam situasi yang tidak terduga. Diharapkan kerangka kerja ini dapat digunakan untuk membangun kesadaran dalam menerapkan PSAK 71 secara optimal, agar kebijakan yang tergolong baru ini mampu memberikan dampak besar bagi Indonesia di masa depan. Terakhir, pembahasan dari makalah ini akan disimpulkan, agar dapat menjadi sebuah kajian yang lengkap.

\section{Tujuan}

Untuk memberikan gambaran kepada sektor perbankan serta perusahaan pemberi kredit dimana PSAK 71 sebagai acuan dalam menyediakan provisi kerugian pinjaman yang cukup guna memberikan kelonggaran pembayaran kredit kepada debitur. Sehingga mampu berguna untuk menjaga laporan keuangan bank agar tetap lancar, yang nantinya mampu menstimulus pertumbuhan ekonomi nasional di tengah kondisi pandemi Covid-19.

\section{Kerangka Teoretis dan Hipotesis}

\section{Tinjauan Pustaka}

Corona Virus Disease (Covid-19)

Pandemi Covid-19 menjadi perhatian serius hampir seluruh negara di dunia. Sejak awal mula munculnya corona virus di Wuhan, Tiongkok bulan Desember 2019, penyebaran virus ini begitu cepat ke negara lainnya. Merebaknya Covid-19 ini menyebabkan siklus perdagangan, ekonomi, kesehatan dan bidang lainnya baik nasional maupun internasional menjadi terhambat. Pada bidang ekonomi, tidak hanya perusahaan besar saja yang mengalami guncangan keuangan, usahausaha start up yang baru meniti karir pun tidak sedikit yang memutuskan untuk menutup usahanya (Yohana Arta Uli, 2020).

Jika usaha tersebut tidak berlanjut, kredit terhadap bank dapat tersendat namun risikonya cukup kecil dikarenakan jumlah pinjamannya pun tidak banyak dibandingkan dengan membuka usaha besar. Sehingga dengan adanya wabah ini membuat sektor perbankan goyah dalam pemberian kredit. Pada kuartal pertama tahun 2020 bulan Januari hingga Maret sebelum wabah ini terjadi rasio Non Performing Loan (NPL) mencapai angka 
2,77\% dimana angka tersebut mengalami kenaikan sebesar $0,47 \%$ dari awal kuartal pertama tahun 2019, yaitu sebesar 2,30\% menurut Wimboh Santoso Ketua Otoritas Jasa Keuangan (dalam finansial.bisnis.com). Sehingga dengan adanya wabah ini dapat diprediksikan kenaikan NPL dapat lebih tinggi lagi.

\section{PSAK 71 dan IFRS 9}

PSAK 71 merupakan standar baru dalam penyusunan instrumen keuangan yang berlaku efektif sejak 1 Januari 2020 sebagai pengganti dari PSAK 55 yang mengadopsi IAS 39. PSAK 71 membuat volatilitas pada laporan laba rugi, pengakuan di awal atas Cadangan Kerugian Penurunan Nilai (CKPN), dan suatu persyaratan baru dalam pengungkapan (PWC, 2019). Ekspektasi kerugian pada PSAK 71 telah dibentuk sejak pertama kali kredit diberikan. Sebagai pengadopsi IFRS 9 yang telah jalan lebih dahulu, PSAK 71 kini merevisi aturan klasifikasi aset tetap yang meliputi pencadangan atas penurunan nilai aset di awal. Hal ini diyakini sebagai antisipasi atas kerugian yang terjadi oleh karena kredit macet bagi perusahaan atau perbankan. Dengan berlaku efektifnya PSAK 71 BCA menunjukkan penurunan Capital Adequacy Ratio (CAR).

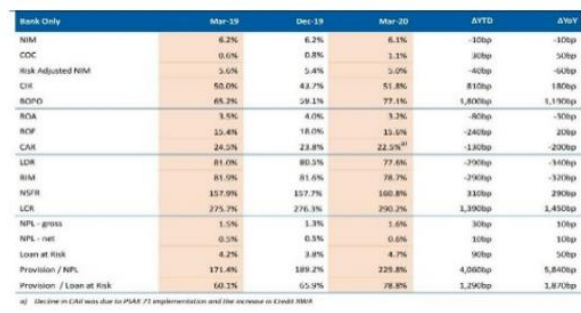

Gambar 1

Rasio Laporan Keuangan Interim BCA Bank Indonesia

Dapat dilihat pada kolom CAR terdapat penurunan sebesar 2\% dari Maret 2019

112 sampai Maret 2020. Keterangan pada angka tersebut juga menjelaskan bahwa penurunan CAR dikarenakan adanya adaptasi PSAK 71. Antisipasi untuk melakukan pencadangan dengan perkiraan masa depan (forward looking) lebih menguntungkan walaupun pada awalnya cukup menekan laba perbankan. Namun jika terjadi keadaan gagal bayar, bank tidak mengalami kerugian seketika. Sehingga bank dapat terhindar dari pengalokasian prosiklikal.

Keterkaitan Covid-19, Perbankan, dan PSAK 71

Sejalan dengan efektifitas penerapan PSAK 71 mulai tahun 2020, dampak perekonomian yang dirasakan saat ini tentunya diprediksi membuat pihak bank mengalami kewalahan untuk membentuk CKPN, dimana mereka harus membentuk pencadangan seketika ketika kredit diberikan. Namun di sisi lain memungkinkan banyaknya perusahaan yang telah mengajukan pinjaman dengan risiko tinggi sebelum penerapan PSAK 71 menyatakan tidak dapat melanjutkan kredit pada saat ini yang membuat bank harus menanggung CKPN yang belum dibuat sebelumnya. Tidak hanya kredit macet saja, konsumsi masyarakat pun berkurang. Dilihat dari data Bank Indonesia mengestimasikan Gross Domestic Product (GDP) lebih rendah 2,7\% dari realisasi GDP tahun 2019.

\begin{tabular}{|c|c|c|}
\hline & FY19 & $\begin{array}{c}\text { FY20 } \\
\text { BI Estimates }\end{array}$ \\
\hline Real GDP & $5.0 \%$ & $2.3 \%$ \\
\hline CPI & $2.7 \%$ & $2-4 \%$ \\
\hline BI 7-D Rate & $5.00 \%$ & na \\
\hline USD/IDR & 13,866 & $14,900-15,500$ \\
\hline CAD (\% of GDP) & $-2.7 \%$ & na \\
\hline \multicolumn{3}{|l|}{ Source: Bonk Indonesia } \\
\hline Analysts Meeting 1020 & & \\
\hline Estimas & $\begin{array}{l}\text { Jamb } \\
\text { P oleh } \\
\text { k Inc }\end{array}$ & k Indonesia \\
\hline
\end{tabular}




\section{Akuntansi Perbankan}

Karena perilaku pembentukan provisi kredit macet memiliki efek prosiklikal antara pembentukan provisi kredit macet dan laba perbankan. Efek ini menunjukkan bahwa pembentukan ketentuan kerugian pinjaman yang rendah akan membuat laba perbankan meningkat, sedangkan pembentukan ketentuan pinjaman-kerugian yang tinggi akan membuat laba perbankan rendah. Untuk menanggapi efek prosiklikal dari Dewan Standar Akuntansi Keuangan (DSAK), penerapan PSAK 71 menggantikan PSAK 55. Dampak penerapan PSAK 71 terhadap aturan akuntansi kredit muncul dalam aspek pengukuran dan penyajian. PSAK 71 ini menerapkan Expected Credit Loss (ECL) (Witjaksono, 2017). Aplikasi ini diharapkan memiliki manfaat cadangan dinamis menurut (Ardhiemus, 2017) di mana ketentuan kerugian pinjaman ini dapat mencegah pemberian pinjaman berlebihan selama periode ekspansi karena pinjaman harus disertai dengan pembentukan ketentuan kerugian pinjaman. Hal ini juga bermanfaat untuk memperkuat daya tahan bank dalam kondisi ekonomi yang menurun. Dan yang terakhir adalah laba yang halus sehingga fluktuasi laba menjadi minimal

\section{Metode Penelitian}

Penyusunan makalah ini menggunakan pendekatan kualitatif, dimana analisa didasarkan pada data sekunder yang berasal dari website resmi Ikatan Akuntan Indonesia (IAI), Otoritas Jasa Keuangan (OJK), beberapa bank nasional dan over draft dari PSAK 71. Fokus penelitian ini ada pada penerapan adaptasi PSAK 71 mengenai ketentuan pencadangan kerugian pinjaman terhadap penurunan ekonomi yang disebabkan oleh peristiwa yang tidak dapat diprediksi. Dengan cara menganalisis dampak adaptasi PSAK 71 pada masa pandemi Covid-19, akan menghasilkan bagaimana bank dapat menerapkan PSAK 71 terhadap entitas yang berperan sebagai debitur sehingga berguna terhadap ekonomi masa depan mereka.

\section{Hasil Penelitian dan Pembahasan}

PSAK 71 dikeluarkan untuk mengantikan PSAK 55 yang mengadopsi IAS 39 tentang Instrumen Keuangan: Pengakuan dan Pengukuran yang telah digunakan sejak 2004. PSAK 55 menggunakan Loss Incurred Method (LIM), sehingga penyisihan kerugian pinjaman akan dilakukan setelah ada beberapa peristiwa yang tidak terduga yang menyebabkan penurunan nilai pada entitas keuangan. Sedangkan, PSAK 71 menggunakan ECL yang membuat bank harus menyediakan CKPN berdasarkan ekspektasi kehilangan kredit selama dua belas bulan ke depan. Sebagai contoh perhitungan terkait PSAK 55 dan PSAK 71, diasumsikan pinjaman sebesar Rp. 5.000.000 jika menggunakan PSAK 55 pengakuan kerugian tidak tertagih dilakukan di akhir dengan langsung mengeliminasi 5 juta, hal tersebut akan mengakibatkan kerugian pada bank. Sedangkan, PSAK 71 pencadangan dilakukan di awal sehingga pada akhir periode bank tidak mengalami rugi terlalu besar.

Perbankan harus memberikan penyisihan kerugian penurunan nilai yang lebih besar dari sebelumnya terkait kredit macet. Metode untuk menghitung provisi kerugian-pinjaman adalah dengan kombinasi data kerugian historis, kondisi aset, kondisi keuangan perusahaan, dan prediksi kondisi ekonomi di masa depan. PSAK 71 dianggap lebih baik dalam pembentukan ECL. Bank yang telah mengimplementasikan PSAK 71 dinilai 
lebih siap ketika mereka harus menghadapi peristiwa yang tidak terduga seperti pandemi Covid-19, dimana perusahaan tidak dapat membayar kredit kepada bank yang mengakibatkan bank harus menggunakan modal mereka untuk menutupinya.

IAI dalam press release nya menetapkan kebijakan bahwa terdapat adaptasi terhadap penggunaan PSAK 71. Adaptasi yang dibuat, khususnya pada PSAK 71 menekankan terkait letak waktu fenomena Covid-19 ini yang tergolong kondisi kini serta perkiraan kondisi masa depan sebagai dampak dari kondisi kini.

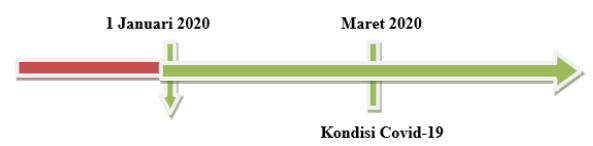

\section{Gambar 3 \\ Garis Waktu Terkait Penentuan Kejadian \\ Sumber : Press Release Dewan Standar Akuntansi Keuangan(DSAK)}

Selain itu dalam press release juga ditekankan bagaimana cara entitas untuk menilai model ECL yang telah dirancang yaitu dengan mempertimbangkan apakah terdapat Peningkatan Signifikan Risiko Kredit (PSRK) dengan cara melakukan tracing terhadap model yang ada. Tracing dapat dilakukan dengan mempertimbangkan beberapa hal yang berkaitan dengan kondisi perekonomian perusahaan.

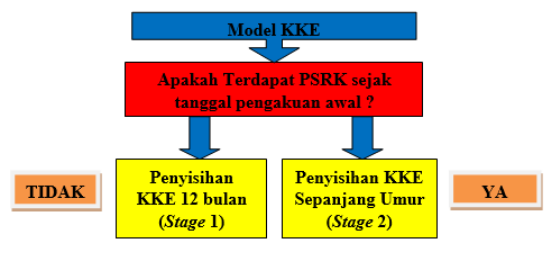

\section{Gambar 4}

Model Kerugian Kredit Ekspektasian (KKE)

Sumber : Press Release Dewan Standar Akuntansi Keuangan(DSAK)

Dalam praktiknya, PSAK 71 mengadopsi principal base yang dapat diartikan bahwa fenomena Covid-19 serta relaksasi dari pemerintah tidak dapat langsung disimpulkan bahwa jika tidak terjadi peningkatan signifikan risiko kredit (PSRK) maka otomatis berada pada stage 1 , begitu juga jika terjadi peningkatan signifikan risiko kredit (PSRK) maka otomatis berada pada stage 2. Penarikan kesimpulan harus melalui pertimbangan-pertimbangan seperti kondisi keuangan debitur, prospek usaha debitur serta dampak nilai waktu uang yang berkaitan dengan waktu pembayaran. Oleh karena itu, penelitian ini menghasilkan sebuah kerangka kerja yang dapat memberikan pandangan kepada sektor perbankan dalam menyikapi pembentukan Expected Credit Loss (ECL) pada masa pandemi Covid-19 dengan tetap memperhatikan keselamatan ekonomi nasional. 


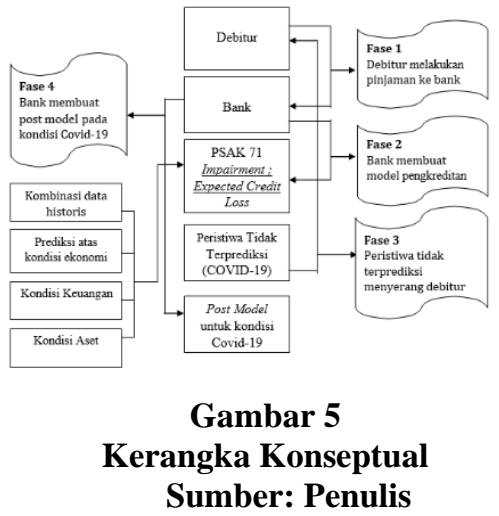

Melalui kerangka kerja diatas, dapat dilihat gambaran besar tentang dampak penerapan PSAK 71, serta berguna dalam membangun kesadaran untuk penerapan PSAK 71 yang optimal. Pada fase 1 debitur mengajukan pinjaman ke bank, fase 2 bank akan membuat model pengkreditan yang akan diberikan kepada debitur berdasarkan data perusahaan baik masa lalu, masa sekarang maupun di masa yang akan datang, yaitu kombinasi data historis, prediksi atas kondisi ekonomi, kondisi keuangan, dan kondisi aset.

Ketika penerapan PSAK 71, bank menyediakan ketentuan kerugian pinjaman untuk semua kategori kredit atau pinjaman dalam situasi saat ini, sehingga pada awal pemberian pinjaman CAR bank akan turun dikarenakan modal yang dimiliki lebih sedikit dibandingkan dengan penerapan PSAK 55. Tujuan ini sebenarnya baik, dimana ketika terjadi krisis ekonomi bank telah memiliki cadangan yang cukup untuk mengantisipasi adanya gagal bayar. Bank juga dapat lebih berhati-hati dalam memberikan pinjaman dengan melihat potensi awal debitur sebelum memberikan kredit, karena jika keuangan debitur cukup buruk pada awalnya maka akan timbul dampak buruk pada masa depan terutama ketika terjadi fenomena seperti Covid-19 saat ini akan memiliki risiko yang sangat signifikan terhadap kondisi bank.

Fase ke 3 disimulasikan ketika terjadi peristiwa yang tidak diprediksi bank akan memasuki fase 4 yaitu membuat penerapan post model seperti pada saat ini, dimana akan dibagi menjadi 2 stage, dimana stage 1 merupakan penerapan PSAK 71 dengan jangka waktu normal yaitu 1 tahun, dan stage 2 dimana pencadangan umur piutang dijadikan seumur hidup. Posisi stage 2 tidak sertamerta diberikan begitu saja kepada perusahaan yang menyatakan terkena dampak signifikan. Bank akan melakukan analisis terkait data debitur yang sudah diserahkan pada saat pinjaman awal dan membandingkannya dengan keadaan debitur ketika terjadinya pandemi Covid19. Setelah bank telah menentukan perusahaan tersebut memenuhi kualifikasi stage 2, maka akan diterapkan pencadangan seumur hidup atas pinjaman perusahaan tersebut.

Dengan penerapan PSAK 71 sesuai press release DSAK dan alur dari kerangka konseptual dapat dilihat bahwa bank mampu menahan perlambatan pertumbuhan ekonomi. Dikarenakan bank dapat memperkuat stabilitas sistem keuangan perekonomian negara ketika terdapat kondisi yang tidak mendukung seperti dampak pandemi Covid-19 yang terjadi di Indonesia. Pencadangan yang dilakukan di awal akan sangat menguntungkan bank di masa depan dan pada normalnya perputaran pengembalian piutang bank dengan PSAK 71 normal hanya1 tahun saja, sehingga kemungkinan terbayarnya besar. Sedangkan untuk post model, bank akan mencadangkan seumur hidup piutang tersebut namun tidak berarti bank menghapuskan piutangnya, perusahaan dapat membayar di kemudian hari tanpa batasan waktu, sehingga pendapatan dari masa lalu di masa depan bank mampu menopang jika modal bank 
mengalami kemerosotan yang tidak terduga.

\section{Simpulan dan Saran}

\section{Simpulan}

Penggunaan PSAK 71 sejak tahun 2020, telah dijalankan oleh bank ataupun perusahaan lainnya sesuai dengan ketentuan umum yang ditetapkan dalam PSAK 71. Namun setelah timbulnya pandemi Covid-19 yang mengubah berbagai aspek perekonomian, IAI mengeluarkan press release baru yang menyesuaikan penggunaan PSAK 71 sesuai dengan kondisi saat ini. Hal ini mempertimbangkan pemberian kredit yang akan diberikan bank kepada debitur dengan memperhatikan pencadangan model ECL yang dapat meningkatkan risiko terhadap PSRK. Sehingga, dari adanya keadaan yang tidak terduga saat ini, PSAK 71 yang diadaptasikan khusus mampu menyelamatkan perekonomian di masa mendatang dikarenakan tujuan awalnya adalah untuk masa depan yang lebih baik dan menjamin dimana CAR bank akan menurun saat pinjaman diberikan sehingga ketika pinjaman tersebut ada di stage 2 (pencadangan seumur hidup) tidak akan mengganggu CAR bank di masa yang akan datang.

Selain itu, regulasi tersebut tidak hanya serta merta diterapkan ke semua entitas. Namun, hanya entitas yang benarbenar memenuhi kualifikasi dari kerangka kerja yang dapat digolongkan pada stage 2 . Sehingga tidak banyak perusahaan yang umur piutangnya dinilai terlalu dini untuk dikategorikan pada stage 2 . Hal ini dapat memberikan keuntungan sekaligus kerugian bagi bank. Keuntungan yang dapat diperoleh dalam hal ini adalah ketika time value money dengan asumsi tidak terjadi inflasi, maka bank akan memperoleh keuntungan dari bunga yang dibayarkan. Namun di lain sisi, kerugian yang dapat dialami oleh bank adalah hilangnya kesempatan ekonomis yang seharusnya dimiliki oleh bank akibat adanya risiko gagal kredit dari pihak debitur atas pinjaman yang diberikan.

\section{Saran}

Penelitian saat ini masih terbatas dengan data yang diperoleh dikarenakan pengkajian data menggunakan laporan keuangan interim kuartal pertama tahun 2020, dan objek penelitian berfokus pada pihak bank saja dalam pemberian pinjaman. Penelitian selanjutnya dapat dilakukan dengan mengkaji laporan keuangan perusahaan periode 2020 yang terbit pada tahun 2021 dimana akan lebih menghasilkan kajian yang lebih valid karena ketersediaan data sudah lengkap dan bisa memperluas objek penelitian selain bank.

\section{Daftar Pustaka}

BankCentral Asia. 2020. Laporan IkhtisarKeuangan.https://www.bca.co. id/tentang-bca/hubungan-investor/ laporan-keuangan. Diakses tanggal 30 September 2020

Dewan Standar Akuntansi Keuangan Ikatan Akuntan Indonesia. 2018. Standar Akuntansi Keuangan Efektif per 1 Januari 2018. Jakarta: Ikatan Akuntan Indonesia.

Dewan Standar Akuntansi Keuangan Ikatan Akuntan Indonesia. 2018. Standar Akuntansi Keuangan Efektif per 1 Januari 2019 \& 2020. Jakarta: Ikatan Akuntan Indonesia.

Ikatan Akuntan Indonesia. (2020, 1 April). Press Release-Dampak Pandemi COVID-19 Terhadap Penerapan PSAK 8 Peristiwa Setelah Pelaporan 
dan PSAK71 Instrumen Keuangan. http://iaiglobal.or.id/v03/beritakegiatan/detailberita-1231-pressrelease-\%E2\%80\%93-dampakpandemi covid19-terhadap-penerapanpsak-8-peristiwa-setelah-periodepelaporan- dan-psak-71-instrumenkeuangan. Diakses tanggal 1 Oktober 2020.

Ikatan Akuntan Indonesia. (2020, 1 April). Press Release-Dampak Pandemi COVID-19 Terhadap Penerapan PSAK 8 Peristiwa Setelah Pelaporan dan PSAK 71 Instrumen Keuangan.http://iaiglobal.or.id/v03/berit a- kegiatan/detailberita-1231-pressrelease-\%E2\%80\%93-dampak-pandemi covid19-terhadap-penerapan-psak-8peristiwa-setelah-periode-pelaporandan-psak-71-instrumen-keuangan. Diakses tanggal 1 Oktober 2020.

PWC. (2019, 9 Mei). Standar Akuntansi Baru PSAK 71,72, 73, berlaku 2020, Ini Perbedaannya. https://www.pwc.com/id/en/mediacentre/pwc-innews/2019/indonesian/standarakuntansi-baru-berlaku-2020.html. Diakses tanggal 1 Oktober 2020.

Syafina, Dea Chadiza. (2019, 24 September). Bagaimana PSAK 71 Mempengaruhi Perbankan ?. https://tirto.id/bagaimana-psak-71memengaruhi-perbankan-ehPf. Diakses tanggal 30 September 2020.

Uly, Yohana Artha. (2020, 9 Juli). Kurang Dari 50 Persen Startup yang Mampu Bertahan Di Tengah Krisis AkibatCovid-19. https://money.kompas.com/read/2020/0 7/09/191300126/kurang-dari-50persen-startup-yang-mampu-bertahandi-tengah-krisis-akibat. Diakses tanggal 10 Oktober 2020.
WHO. (2020,15April). Q\&A on Coronaviruses(COVID-19).

https://www.who.int/emergencies/dise ases/novel-coronavirus-

2019/question-and-answers-hub/q-adetail/q-a-coronaviruses. Diakses tanggal 28 September 2020

Wiratmini, Ni Putu Eka. (2020, 11 Mei). Maret 2020 Kredit Bank Bermasalah Naik, Sektor Ini Pendukungnya.https://finansial.bisnis. com/read/20200511/90/1238730/mare t-2020-kredit-bermasalah-bank-naiksektor-ini-pendorongnya.Diakses tanggal 30 September 2020. 